\title{
Histopathology of cultured shrimp showing gross signs of yellow head syndrome and white spot syndrome during 1994 Indian epizootics
}

\author{
C. V. Mohan, K. M. Shankar, S. Kulkarni, P. M. Sudha \\ Fish Pathology Laboratory, Department of Aquaculture, College of Fisheries, UAS, Mangalore, India
}

\begin{abstract}
Two epizootics of cultured shrimp occurred in India in 1994. The first case of mass mortalities of tiger shrimp Penaeus monodon in July 1994 was very similar to that caused by yellowhead virus (YHV) infection with regard to gross clinical signs, host species and size of shrimp affected, but it was histologically atypical. Very interestingly, intranuclear inclusions typical of a white spot syndrome virus (WSSV) infection were present in shrimp showing gross signs of yellow head syndrome, suggesting a dual infection. The second case of mass mortalities of $P$. monodon and $P$. indicus of all age groups and sizes in November 1994 was typical of a WSSV infection, clinically and histopathologically. Densely stained, round intracytoplasmic inclusions typical for YHV infection found in the lymphoid organ and haematopoietic tissue of WSSV-infected shrimp indicated a possibile dual infection.
\end{abstract}

KEY WORDS: Yellow head syndrome White spot syndrome - Dual infection Histopathology . Cultured penaeids - India

\section{INTRODUCTION}

Intensive shrimp farming has made significant progress in several maritime states in India. In 1994, 2 epizootics with distinctly different gross signs were associated with mass mortalites of cultured shrimp in India (Mohan 1996). The present paper describes the histopathological features of these 2 syndromes and provides evidence to suggest that the first epizootic was grossly like a yellow head virus (YHV) infection, but it was histologically atypical. The second outbreak was grossly and histologically typical of white spot syndrome virus (WSSV) infection. The paper also provides histological evidence for dual YHV/WSSV infections during both of the epizootics.

\section{MATERIALS AND METHODS}

Samples of affected shrimp were fixed by the authors and by farmers in $10 \%$ neutral buffered formalin at farm sites and later brought to the laboratory for sectioning. Information on case history and clinical signs was also collected for each sample. Fixed tissues were processed for standard histological examination (Lightner 1996) and photomicrography. Approximately 30 and 100 shrimps were examined histologically from shrimp exhibiting gross signs of yellow head syndrome (YHS) and white spot syndrome (WSS), respectively.

\section{RESULTS}

Yellow head syndrome

During July to August 1994, YHS affected shrimp in grow-out ponds near Kandeleru Creek in Gudur, Andhra Pradesh, in a large area along the east coast of India which has many shrimp farms. Infected shrimp refused feed, came to pond margins, showed yellowing of the cepahlothorax and started to die. There were no visible white spots on the inner side of the carapace. Mass mortality of 70 to $100 \%$ occurred within 2 to $3 \mathrm{~d}$ after the appearance of clinical signs. Only 50 to $70 \mathrm{~d}$ old juvenile and adolescent tiger shrimp Penaeus monodon were affected. White shrimp $P$. indicus co- 


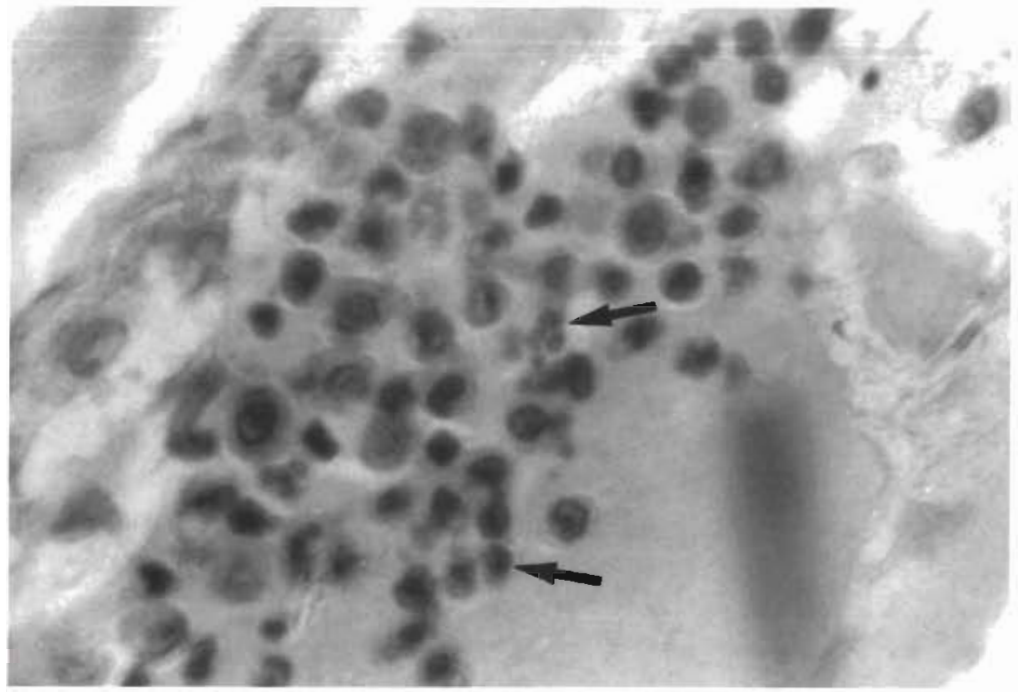

Fig. 1. Pyknotic and karyorrhectic haemocytes (arrows) in haemal sinuses below cuticular epidermis in Penaeus monodon showing gross signs of yellow head syndrome (YHS). $H \& E_{;} \times 1000$

cultured with tiger shrimp showed no clinical signs and were apparently unaffected. Further outbreaks with a similar clinical history and gross signs have not been reported from anywhere else in India.

Pyknotic and karyorrhectic haemocytes were consistently observed in haemal sinuses of various tissues (Fig. 1). Perinuclear intracytoplasmic inclusion bodies were not present in the gills, lymphoid organ or haematopoietic tissue. However, intracytoplasmic inclusion-like bodies were observed in the haemocytes present in the hepatopancreas that were associated with a massive inflammatory response. In all the samples examined, the cuticular epidermis and connective tissue cells had hypertrophied nuclei with pale basophilic intranuclear inclusion bodies (Fig. 2). Large numbers of nongranular haemocytes were observed in the haemal sinuses immediately below the cuticular epidermal cells having intranuclear inclusions.

In addition, the hepatopancreas showed pathological features consistent with an enteric form of bacterial disease. Massive necrosis of the tubular epithelial cells with rounding, pyknosis and sloughing into the lumen of tubules were common. Haemocyte infiltration into the intertubular spaces, encapsulation of damaged tubules and nodule formation were apparent. Bacterial infection was also evident in tubule Iumens. Large numbers of haemocytes were present in the tubular sinuses of the hepatopancreas. Significant numbers of large active phagocytic cells were observed in the heart tissues of infected individuals.

\section{White spot syndrome}

During November to December 1994, a second epizootic was observed in Nellore, Andhra Pradesh, close to the area of the first epizootic. Since then, the syndrome has spread to several farms in different parts of India, affecting both Penaeus monodon and $P$. indicus of all age and size groups. The epizootic occurred in all types of rearing systems and at various stocking densities. Diseased shrimp refused feed, collected at pond margins, had red to pink-red discoloration of the body, exhibited broken antennae and had damaged appendages. The most conspicuous feature of the syndrome was small to large white spots on the inner side of the carapace, especially in the cephalothoracic region. Shrimp mortality began gradually, but within 5 to $7 \mathrm{~d}$ from the appearance of the first gross signs mass mortality occurred.

The histopathological features associated with WSS were consistent in all the affected shrimp examined. The subcuticular epithelium, gills, lymphoid organ, subcuticular epithelium of the stomach (Fig. 3), antennal gland, haematopoeitic tissue, vas deferens, con-

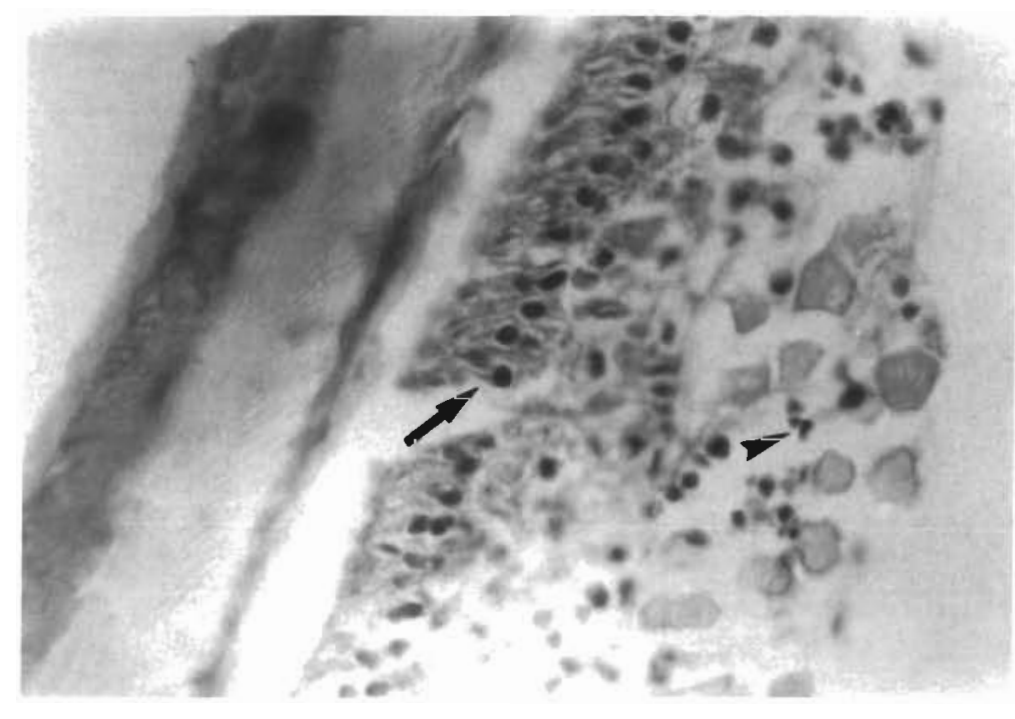

Fig. 2. Cuticular epithelium with large basophilic intranuclear inclusion bodies characteristic of white spot syndrome virus (WSSV) infection (arrow) in Penaeus monodon showing gross signs of YHS. Note the presence of pyknotic haemocytes in the haemal sinus (arrowhead). $H \& E_{i} \times 400$ 


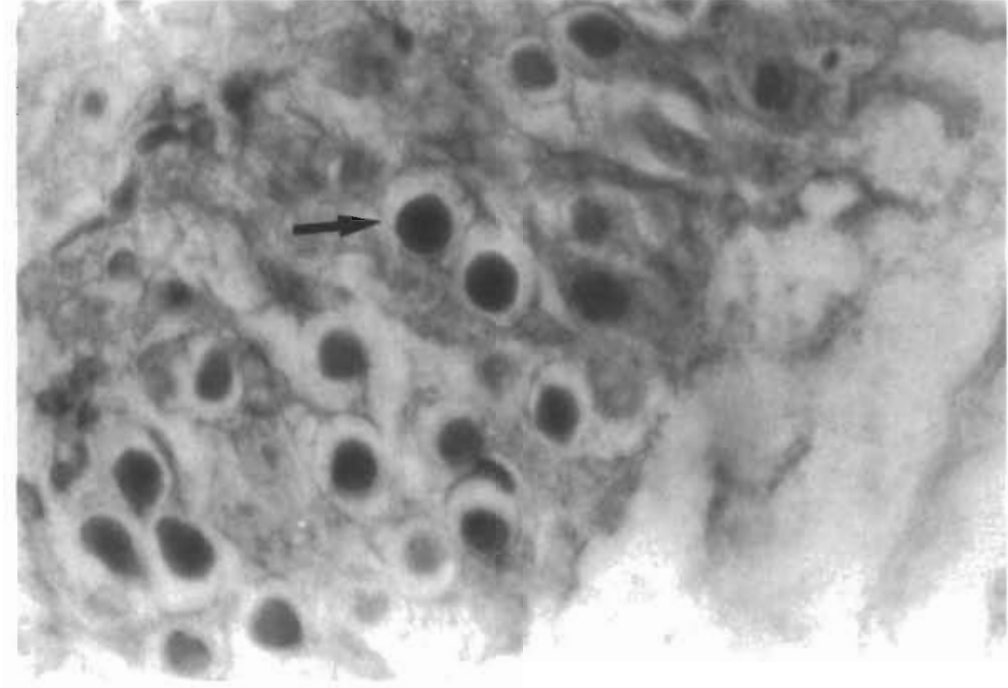

Fig. 3. Subcuticular gut epithelium with hypertrophied nuclei containing basophilic intranuclear inclusion bodies characteristic of WSSV infection (arrow) in Penaeus monodon showing gross signs of white spot syndrome (WSS). $\mathrm{H} \& \mathrm{E}_{;} \times 1000$

nective tissue of the hepatopancreas and ovary, general connective tissues and ventral nerve cord had hypertrophied nuclei with pale basophilic intranuclear inclusion bodies. The intranuclear inclusions were eosinophilic in their initial stages with a clear zone around the inclusion. They gradually turned basophilic and expanded to occupy the whole nucleus. Detailed examination of lymphoid organ and haematopoietic tissue of shrimp showing gross signs of WSS revealed what appeared to be densely stained, round intracytoplasmic inclusions, in addition to hypertrophied nuclei (Fig. 4). There was no evidence of pathology associated with bacterial infection in any of the shrimp having gross signs of WSS.

\section{DISCUSSION}

The first case of apparent YHS, which occurred during July to August 1994, was very similar to yellow head disease in terms of gross signs, severity, host species and size affected, but it was histologically atypical in that intensely basophilic, cytoplasmic inclusions were absent in the gills, lymphoid organ and haematopoeitic tissue. YHV was reported for the first time in Thailand (Boonyaratpalin et al. 1992) and it is suspected to be the cause of many mass mortalities of shrimp in several countries of Southeast Asia. Natural infections of YHV, later described as an RNA virus (Wongteerasupaya et al. 1995a), have been definitively diagnosed only in Penaeus monodon in Thailand. Our observation that $P$. indicus present with $P$. monodon did not show signs of YHS was similar to observations in Thailand, where $P$. merguensis co-cultured with YHV-infected $P$. monodon also failed to show signs of yellow head disease (Lightner 1996). This possibly suggests host specificity of YHV

Histopathological studies did not show evidence of the characteristic intracytoplasmic inclusions of YHV in the gills, lymphoid organ and haematopoeitic tissue, but pyknotic and karyorrhectic haemocytes were observed in haemal sinuses of some of these target tissues. Intracytoplasmic inclusion-like bodies were also present in inflammatory haemocytes associated with the enteric bacterial infection observed in the hepatopancreas. It is possibile that these inclusion-like bodies were phagocytosed bacteria. In addition, large numbers of non-granular haemocytes were also seen in the sinuses of various tissues. These pathological changes are similar to the pathology described for YHV infection (Lightner 1996). In the case of a concomitant septicaemia, it may be difficult to diagnose YHV infections unless in situ hybridization or electron microscopy techniques are used.

The other pathological features described here, such as tissue necrosis, haemocytic infiltration, encapsula-

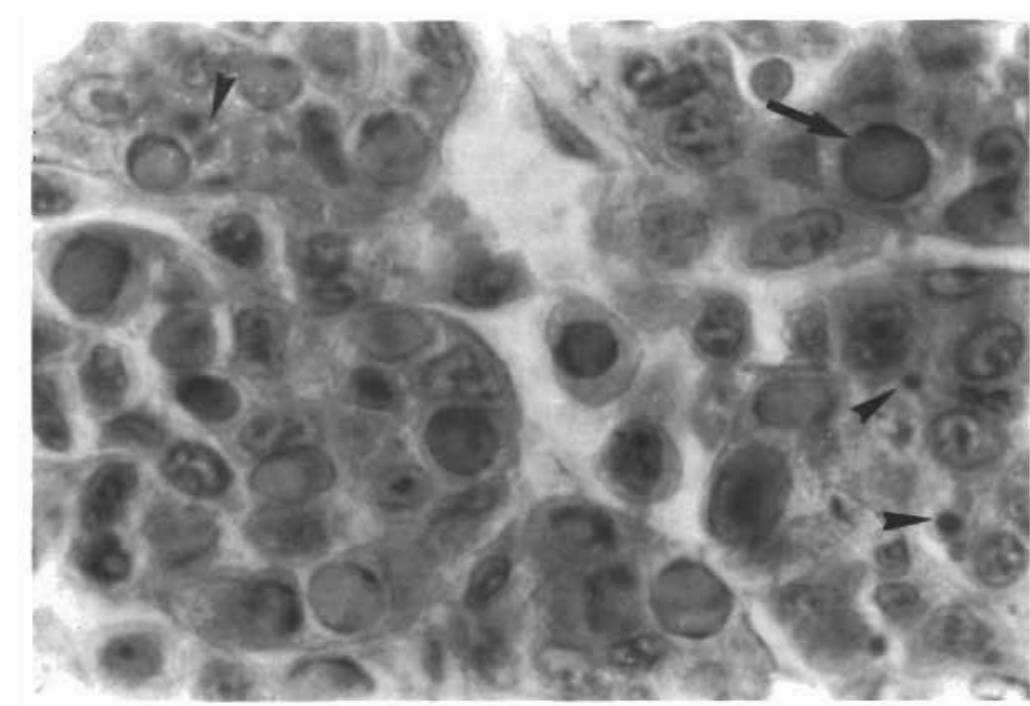

Fig. 4. Intranuclear inclusion bodies characteristic of WSSV infection (arrow) in the haematopoeitic tissue cells of Penaeus monodon showing gross signs of WSS. Note the presence of large numbers of darkly stained, round intracytoplasmic inclusion bodies (arrowheads). H\&E; $\times 1000$ 
tion and nodule formation in the hepatopancreas, were associated with an enteric bacterial infection that was present in shrimp displaying gross signs of YHS. The massive pathology and haemocytic inflammation observed in the hepatopancreas may have contributed to the yellow coloration of the cephalothorax. The lesions described appear to be associated with multiple infections having bacterial and viral etiology. Since the outbreak was short-lived and confined to one farming area, large numbers of samples could not be histologically examined and, hence, the possibility of YHV being present at that time cannot be totally ruled out.

An interesting feature in our case of YHS was the presence of intranuclear inclusion bodies in the subcuticular shell epithelium and connective tissue. These intranuclear basophilic inclusions are characteristic of WSSV, the etiological agent of WSS (Lightner 1996). From the limited histopathological evidence, it appears that the YHS observed in India for the first time had a mixed etiology with definite involvement of WSSV and enteric bacteria, and probably YHV. The WSS that occurred subsequently during November to December 1994 at farms in Nellore, Andhra Pradesh, followed numerous regional cyclones of 1 to $2 \mathrm{~d}$ duration. This region was near Kandeleru Creek, where YHS was recorded earlier in July 1994. The disease has since spread to farms along both the east and west coasts of India and has re-occurred at certain farm sites 2 to 3 times (Mohan 1996). Unlike YHS, both Penaeus monodon and $P$. indicus of all sizes and ages were affected and all the infected shrimp had the distinctive white spots on the inner side of the carapace. Histologically, all affected cells in the target tissues had hypertrophied nuclei with basophilic intranuclear inclusion bodies, which is a diagnostic feature of WSSV (Wongteerasupaya et al. 1995b, Lightner 1996, Lo et al. 1996). The tissue level severity in the natural WSSV infections suggested that WSSV was the cause of death in the white spot outbreaks. The presence of intracytoplasmic inclusions typical for YHV in shrimp which were clinically and histologically positive for WSSV indicated the possibility of dual infections.

Dual YHV/WSSV infections have been observed in Penaeus monodon (Wongteerasupaya et al. 1995b, Flegel 1997). Indeed, WSSV was first seen and purified in Thailand during an attempt to purify YHV from experimentally infected $P$. monodon (Wongteerasupaya et al. 1995b). The authors speculated that preferential amplification of WSSV had occurred in succeeding groups of experimental animals dually infected with YHV and WSSV. They also recommended that the significance and impact of such dual infections be further investigated. The present findings of WSSV inclusions in farmed shrimp showing gross signs of
YHS and of intracytoplasmic inclusions (likely YHV) in farmed shrimp showing gross signs and histopathology of WSSV infection supports their suggestion that some interaction may occur between these 2 viruses.

There is no obvious explanation why the Indian outbreak of YHS was confined to only one region, occurred for only a short time and did not reoccur later. The subsequent occurrence of WSS may have been associated with the earlier YHS outbreak. Why gross YHS with atypical histology occurred together with typical WSSV histopathlogy in the absence of WSS, why this was later followed by typical WSS showing WSSV/YHV histopathology and why this sequence was confined to one region need to be examined in greater detail. Retrospective analysis of shrimp seed imports to India from Southeast Asian countries during 1993 and 1994 may shed some light on these 2 epizootics that first occurred in India in 1994

Acknowledgements. The authors thank Dr T. M. R. Setty, the Director of the College, and Dr P. Keshavanath, Professor of Aquaculture, for their support and encouragement.

\section{LITERATURE CITED}

Boonyaratpalin S, Supamattaya K, Kasornchandra J, Direkbusaracom S, Aekpanithanpong U, Chantanachooklin C (1992) Non-occluded baculo-like virus, the causative agent of yellow-head disease in the black tiger shrimp Penaeus monodon. Fish Pathol 28:103-109

Flegel TW (1997) Special topic review: major viral diseases of the black tiger prawn (Penaeus monodon) in Thailand. World J Microbiol Biotechnol 13:433-442

Lightner DV (1996) Handbook of diagnostic procedures for diseases of penaeid shrimp. Special publication of the World Aquaculture Society, Baton Rouge, LA

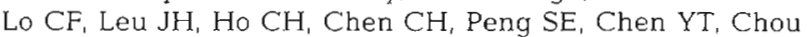
CM, Yeh PY, Huang CJ, Chou HY, Wang CH, Kou GH (1996) Detection of baculovirus associated with white spot syndrome (WSBV) in penaeid shrimps using polymerase chain reaction. Dis Aquat Org 25:133-141

Mohan CV (1996) Health management strategy for a rapidly developing shrimp industry - an Indian perspective. In: Subasinghe RP, Arthur JR, Shariff $M$ (eds) Health management in Asian aquaculture. Proceedings of the Regional Expert Consultation on Aquaculture Heaith Management in Asia and the Pacific. FAO Fisheries Technical Paper 360. FAO, Rome, p 75-87

Wongteerasupaya C, Sriuairatana S, Vickers JE, Akrajamorn A, Boonsaeng V, Panyim S, Tassanakajon A, Withyachumnarnkul B, Flegel TW (1995a) Yellow-head virus of Penaeus monodon is an RNA virus. Dis Aquat Org 22: $45-50$

Wongteerasupaya $C$, Vickers JE, Sriuairatana S. Nash GL. Akrajamorn A, Boonsaeng V, Panyim S, Tassanakajon A, Withyachumnarnkul B, Flegel TW (1995b) A nonoccluded, systemic baculovirus that occurs in the cells of ectodermal and mesodermal origin and causes high mortality in black tiger prawn Penaeus monodon. Dis Aquat Org 21:69-77 